\title{
Pedagogical Content Knowledge of nursing freshman professors in medium-level technical education
}

\author{
Conhecimento Pedagógico de Conteúdo de docentes de enfermagem novatos na educação técnica de nível médio
}

Conocimiento Pedagógico del Contenido de docentes de enfermería novatos en la educación técnica de nivel medio

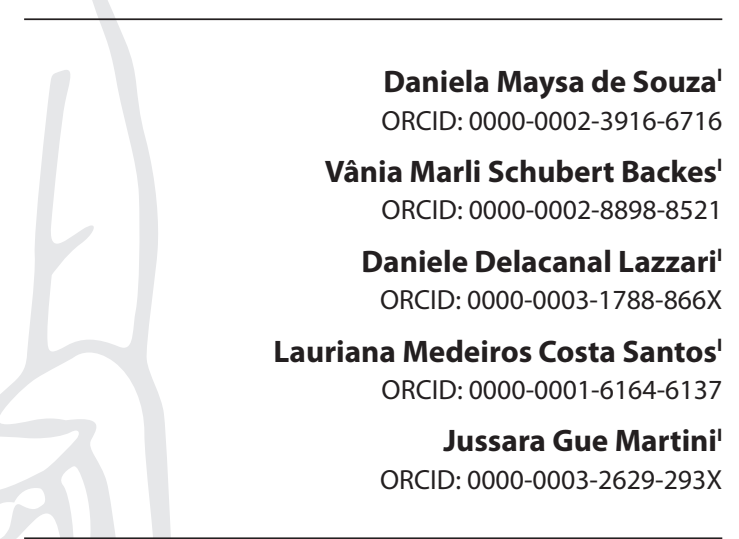

'Universidade Federal de Santa Catarina. Florianópolis, Santa Catarina, Brazil.

How to cite this article: Souza DM, Backes VMS, Lazzari DD, Santos LMC, Martini JG. Pedagogical Content Knowledge of medium-level vocational education nursing freshman professors. Rev Bras Enferm. 2020;73(5):e20180976. doi: http://dx.doi.org/10.1590/0034-7167-2018-0976

\section{Corresponding author:}

Daniela Maysa de Souza

E-mail: danimaysa@gmail.com

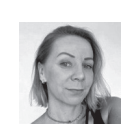

EDITOR IN CHIEF: Antonio José de Almeida Filho ASSOCIATE EDITOR: Italo Rodolfo Silva

Submission: 02-19-2019

Approval: 01-17-2020

\begin{abstract}
Objectives: to analyze the practice and construction processes of Pedagogical Content Knowledge of freshman professors, in secondary education in nursing. Methods: a collective case study with a qualitative approach. Data collection with biographical interview, nonparticipant observation of sessions and group interview. With the results interpreted in the light of Shulman's theoretical framework, content analysis enabled the creation of the category Manifestation of Pedagogical Content Knowledge. Results: predominance of traditional teaching practices, with an attempt at more flexible postures, with pedagogical knowledge and encouragement for student reflection. Final Considerations: the transition from the traditional model to a dialogical teaching (with the student's role) highlights the process of expanding Pedagogical Content Knowledge of, such as learning in and about the practice itself, seeking to strengthen teaching knowledge. A manifestation of reflective thinking was evidenced, with a perception of teaching professionalization.

Descriptors: Faculty, Nursing; Nursing Faculty Practice; Education, Nursing, Associate; Nursing Education Research; Nursing.
\end{abstract}

\section{RESUMO}

Objetivos: analisar os processos de prática e construção do Conhecimento Pedagógico do Conteúdo do professor novato, na educação de nível médio em enfermagem. Métodos: estudo de casos coletivos com abordagem qualitativa. Coleta de dados com entrevista biográfica, observação não participante de sessões e entrevista em grupo. Com os resultados interpretados à luz do referencial teórico de Shulman, a análise de conteúdo possibilitou a criação da categoria Manifestação do Conhecimento Pedagógico do Conteúdo. Resultados: predomínio de práticas tradicionais de ensino, com tentativa de posturas mais flexíveis, com conhecimento pedagógico e estímulo à reflexão discente. Considerações Finais: a transição do modelo tradicional para um ensino dialógico (com protagonismo do aluno) evidencia o processo de expansão do Conhecimento Pedagógico do Conteúdo; como aprendizado na e sobre a própria prática, buscando o fortalecimento dos saberes docentes, evidenciou-se manifestação de pensamento reflexivo, com percepção da profissionalização do ensino. Descritores: Docentes de Enfermagem; Prática do Docente de Enfermagem; Educação Técnica em Enfermagem; Pesquisa em Educação de Enfermagem; Enfermagem.

\section{RESUMEN}

Objetivos: analizar los procesos de práctica y construcción del Conocimiento Pedagógico del Contenido del profesor novato, en la educación de nivel medio en enfermería. Métodos: estudio de casos colectivos con abordaje cualitativo. Recolección de datos con entrevista biográfica, observación no participante de sesiones y entrevista en grupo. Con los resultados interpretados a la luz del referencial teórico de Shulman, el análisis de contenido posibilitó la creación de la categoría Manifestación del Conocimiento Pedagógico del Contenido. Resultados: predominio de prácticas tradicionales de enseñanza, con intento de posturas más flexibles, con conocimiento pedagógico y estímulo a la reflexión discente. Consideraciones Finales: la transición del modelo tradicional a una enseñanza dialógica (con protagonismo del alumno), evidencia el proceso de expansión del conocimiento pedagógico del contenido; como aprendizaje en la propia práctica, buscando el fortalecimiento de los saberes docentes, se evidenció manifestación de pensamiento reflexivo, con percepción de la profesionalización de la enseñanza.

Descriptores: Docentes de Enfermería; Práctica del Docente de Enfermería; Graduación en Auxiliar de Enfermería; Investigación en Educación de Enfermería; Enfermería. 


\section{INTRODUCTION}

In nursing, it is observed, in some cases, that teaching introduction occurs in Medium-Level Vocational Professional Education. This space is often occupied by professors called freshman: newly-trained nurses or newly-trained nurses, who use their knowledge practical theoretical acquired in the graduation and of their personal and professional experience to teach. Professors are considered a freshman when they have professional experience from one to five years, intermediate when they work from six to fourteen years and are experienced. They have more than fifteen years of professional experience in teaching ${ }^{(1-2)}$. It is worth emphasizing that assistance and teaching are different activities, as both require specific knowledge and have their own complexities and specificities.

It is not just about content knowledge for teaching, as both freshman and experienced professors have it, but what do experienced professors know that freshmen are unaware of? There is a solid body of knowledge that distinguishes experienced professors from freshmen, where both undoubtedly present content knowledge to be taught, but their particular way of teaching is what calls attention ${ }^{(3)}$.

It is important to understand how professors transform their understanding of a given content, through their understanding, into something concrete, which makes their students learn, that is, the teaching skill required to transform content into something teachable to students ${ }^{(4)}$.

The knowledge of professors required for teaching, that is, their knowledge base for teaching is presented in seven knowledge, namely: content knowledge; general pedagogical knowledge; curriculum knowledge; Pedagogical Content Knowledge (PCK); knowledge about students and their characteristics; knowledge of the educational context and knowledge of educational purposes, purposes and values and its philosophical and historical basis ${ }^{(5)}$.

This knowledge base is related to the professor's different experiences, identifying four real and potential sources that feed this knowledge base, which occurs through academic training, pedagogical structures and materials, research on the school process and the wisdom from teaching practice ${ }^{(5)}$. Within the knowledge base for teaching, PCK stands out, as it is a personal construction of professors, where their experiences and knowledge merge and summon all the other components of the knowledge base, demonstrating in practice, a particular teaching conception $^{(6)}$. Thus, PCK is the individual manifestation of professors, of their knowledge for teaching, understood as a fusion between content and pedagogy, that is, their ability to transform the incomprehensible into understandable, using pedagogically adaptable forms to the diverse needs of students ${ }^{(5)}$.

PCK manifests itself with the most diverse indicators of interactive teaching, which collaborate for learning, among them, there are, for instance, explanations about the content; transference (teaching and building content); didactic interrogation (formulation of questions); didactic interpretation (based on the knowledge of the student's beliefs about the content. Professors formulate new hypotheses for understanding the proposed theme); expert thinking (exemplification, in class, of the cognitive model used by the professor, to understand a concrete teaching content); interaction (opportunity to expose students' ideas and opinions); didactic empathy (putting themselves in the student's shoes, to identify their difficulties and think of other ways to favor their learning); use of practical examples; use of school board (constituting a projection of professors' thoughts); anthropomorphism (attributing human qualities to physical concepts and phenomena); cognitive conflict (planning dilemmatic situations, which require analysis and judgment by students); perceptual patterns (rapid identification of behaviors that demonstrate difficulties in understanding); situational awareness (ability to organize and manage the class, being aware of everything that is happening in the classroom, while acting); recap of contents, among others ${ }^{(5,7)}$.

Every professor builds his/her PCK in a particular way and there is a chain of events that takes place in the professor's pedagogical practice, supported by the Model of Pedagogical Reasoning and Action (MARP). This movement portrays a cyclical thinking of understanding, transformation, teaching, assessment, reflection and new understanding, which are pedagogically oriented, support MARP(5)

All basic knowledge for teaching, with its sources, is required in MARP, which ends up expressing the professor's teaching method ${ }^{(5)}$. Although the process in MARP is presented sequentially, it does not intend to represent a set of fixed steps, which may occur in a disorderly manner. This self-assessment movement is fed back by a continuous reflective process of professors, which allows them to understand and perceive about their own praxis, with the consequent improvement of their teaching model, as it is at the moment of the development of teaching that PCK effectively manifests itself, being defined as the object of this study.

In order to strengthen pedagogical practices, professor training is necessary, which provides understanding and enables reflection on the professors' own trajectory, so that they can improve their practice ${ }^{(3)}$. The training of bachelors professors is a relatively recent field of studies and still needs to be understood mainly in aspects related to professor professionalization and possibilities for building knowledge through the absence of non-empirical training.

\section{OBJECTIVES}

To analyze the practice and construction processes of Pedagogical Content Knowledge of freshman professors, in Medium-Level Technical Professional Education in nursing.

\section{METHODS}

\section{Ethical aspects}

The study, approved by the Research Ethics Committee of the Universidade Federal de Santa Catarina ( $n^{\circ} 48333815.3 .0000 .0121$ ), respected the ethical aspects as guided by Resolution 466/12 of the Brazilian National Health Board (Conselho Nacional de Saúde). All participants signed the Informed Consent Form, and anonymity was guaranteed, with the use of fictitious names for the professors (Vanessa and Isabella). For student identification, it was used S of student, $V$ of Vanessa and I of Isabella and the numerical sequence in which the records appear (example: Al1 or AV2). 


\section{Type of study}

This is a qualitative and descriptive, of the collective case study type ${ }^{(8)}$. The cases were named as Vanessa and Isabella.

\section{Study setting and participants}

The research was carried out in a private school, in the southern region of Brazil, which offered the Nursing Vocational Training (NVT). The cases were two freshman professors with less than five years of teaching experience at a technical level and the remaining participants were 29 graduating students of the $4^{\text {th }}$ module of the NVT Course and students of the professors in observation (24 students from Vanessa and 25 from Isabella).

\section{Data source}

To select the participants, the 29 graduating students ( $4^{\text {th }}$ module) were asked to indicate the best nurse professor they had in their course during the course and the reason for the indication. Based on the indications, ranking was performed to define the most voted professors. It is justified to choose a good professor (intentional sampling), so that the observation of his practice could answer the objective proposed in this study. The inclusion criteria for the professors were to be nurses and to be carrying out their activities in the NVT Course and as an exclusion criterion, having worked for less than a year in the school under study. As for students, the inclusion criterion was to be regularly enrolled and for the students of the professors who make up the case, the exclusion criterion applied to students who were not taking the disciplines of the professors under observation.

\section{Data collection and organization}

From the ranking, contact was made via e-mail to schedule time, to present the research proposal, but the first professor with the most votes (with 23 nominations), did not accept to participate and the two subsequent professors, Vanessa and Isabella (with eleven) and five nominations, respectively) were invited to participate in the study. Data collection took place from September 2015 to August 2016 and a biographical interview was carried out (transcribed and validated), followed by non-participant observation of the class sessions, at the school premises. These observations consisted of monitoring and filming the entire teaching sessions of the professors, which were recorded with an image and audio recorder, totaling 29 h 30 min of observation (six sessions for each case). At the end of the sixth session of non-participating observations, a group interview (lasting one hour) was carried out separately with the students of the professors under observation (24 students from Vanessa and 25 from Isabella), without the presence of the professors, totaling at the moment, a total of 80 participants ( 29 graduating students; two professors; 24 students from Vanessa and 25 students from Isabella). This interview aimed to know the students' opinion about the practices of the professors under study.

For data analysis, content analysis was chosen, with the help of notes from the field diary, used in all sessions, in which observations were recorded that allowed the classification of the analysis indicators of the PCK of Shulman, present (or not) during the observation of the sessions, which were later transported to the technological tool for qualitative data analysis ATLAS.ti. Thus, the software allowed the individual and comparative analysis of the PCK of the two cases to be carried out, with the results being interpreted in the light of the theoretical framework of Shulman's PCK. The triangulation method was used to analyze the data, based on the semi-structured interview, non-participant observation and group interview data, with the aim of using different sources, to investigate the same phenomenon, enabling the crossing information, giving methodological rigor.

\section{RESULTS}

The two professors (Vanessa and Isabella) appointed by the students are aged 31 and 27 years old, respectively, have graduated in Nursing for five years and are new to teaching (with up to five years of teaching experience). The theoretical framework of Shulman's PCK enabled the creation of a unique category of analysis for each participant, called: Manifestation of Pedagogical Knowledge of Content, where results and cases are presented, following the Pedagogical Action and Reasoning (MARP) model, with its phases of understanding, transformation, teaching, evaluation, reflection and new understanding.

\section{Manifestation of Pedagogical Content Knowledge - Pro- fessor Vanessa}

Vanessa opted for nursing in adolescence, when, when attending a complication, she felt the need to learn more, thus enrolling in the NVT Course and, later, in the nursing undergraduate course. He has a specialization in Surgical Center, working in tertiary care (and currently exclusively dedicated to teaching). His interest in teaching was expressed while working as a nursing technician, as he liked to teach new co-workers, receiving positive feedback from his coordinators, regarding his teaching method. At the end of graduation, she received an invitation to teach in an undergraduate nursing course and, later, in an NVT course and credits the invitation to the fact that she feels safe and has technical mastery and professional experience in the area, which is her understanding. of the need for content knowledge, for teaching.

Whenever a new employee came in, it was always with me that he was [...]. Then I started to really wake up teaching. (Vanessa)

At graduation, she took an optional didactic discipline and to start teaching, she previously participated in pedagogical training meetings offered by the educational institution. By completing five years of teaching experience, she works in the discipline entitled nursing in a Surgical Unit (sessions that were observed).

To carry out content transformation, the preparation begins with the planning of the classes, after the meetings of the beginning of the semester. With the help of a pedagogue, she organizes her classes according to the course plan. Initially, it makes a rescue of the students' previous knowledge, in an attempt to level the class, thus defining the initial approach to the content. 
Firstly, I make a rescue of their knowledge, I want to know what it has to offer me from the content that I am going to address. Then I can understand if the group is in tune or if it clashes a little. (Vanessa)

In the non-participant observation of Vanessa's sessions, at the time of teaching (object of observation), the PCK analysis indicators were identified and recorded and a traditional teaching method was verified, with predominance of content transmission and explanations centered on the figure of the professor. The predominant PCK analysis indicators were: transfer (with 46 records), explanations of the content (19 records) and perceptual patterns (with 10 records). The least observed indicators were: didactic interpretation and reflective dialogue (with one record each); anticipation of content and group work (with three records each) and the absence of expert thought, anthropomorphism, school board, recapitulation of content, good humor, anecdotal stories and situational awareness.

For the evaluation moments, it carries out tests and fixation exercises, indication of complementary literature and the use of routine problems, so that the students collectively solve.

Related to the reason for the indication of the students, she believes she was indicated for her solid basic care practice, prior to teaching, which strengthens her in the classroom, due to her content knowledge. It also uses empathy, sharing its personal learning and coping trajectory in the face of difficulties and the construction of its career, as a way to motivate its students.

I think that today I would not be a professor as they voted, had I not had the practical part of the job. I always think that we can only make a difference as a nurse if we build up little by little. I was a technician, I was an instructor, I was on the other side, with the same nervousness that they have [...] I really tell my story to the student, what I went through, my difficulties, to have really, an approximation to his reality. (Vanessa)

Among the justifications for appointing the best professor, students report the reasons, being:

For professionalism, way of teaching, knowledge and mastery of the subject. By the way of teaching, contagious and showing the daily reality of the nursing technician. (AV1)

The students of the observed class report that the good characteristics of the professor reside in the fact that she uses diversified teaching strategies, with firmness in her answers, with many laboratory practices and mastery of the subject. They consider the excessive amount of content for short class time and the short time to solve the activities requested by the professor to be bad.

Vanessa constantly reflects on her teaching trajectory and, in order to gain a new understanding, she would like to take a specialization or master's degree related to teaching, to strengthen her pedagogical practice, recognizing her as fragility.

\section{Manifestation of Pedagogical Content Knowledge - Pro- fessor Isabella}

Isabella opted for nursing because she was attracted to the maternal and child care area and since childhood, opting for specialization in obstetric nursing, currently working in public health. She was invited to teach in the NVT course and started teaching without previous pedagogical training and in undergraduate courses she did not have subjects related to teaching didactics. she works in the areas of women's health, nursing legislation and health education, with preference for the first, for having professional experience, therefore, her understanding of the content to be taught is strongly anchored in the domain of theoretical content (and practical experience assistance), which gives you greater security to teach classes and promote learning.

Ispeak of what I am passionate about [...] it is easier to transmit the content, which are things that I master, that I know and that I have already experienced [...] I think bringing practical examples also for them, correlating the content with the day to day [...]. (Isabella)

Completing three years of teaching experience, she works in the discipline 'Participate in the planning and organization of nursing care' (sessions in which the observations were made) and the transformation of the content to be taught begins with his lesson planning, which consists of knowledge of the curriculum, to organize the schedule according to the course plan, then prepare the classes, select the contents and adapt them.

In the observation, at the time of teaching, the PCK analysis indicators allowed to identify that its activities are dialogical, with explanations about the content, using examples from the practice itself and encouraging the participation of students, with a predominance of interaction (44 records); explanations of the content (36 records); didactic interrogation (20 records); cognitive conflict (14 records) and use of examples (with 13 records). The least observed indicators were: didactic interpretation and school board (with one record each); anticipation of and recapitulation of content (with two records each) and the absence of anthropomorphism and expert thought.

Isabella makes the assessment of students' learning through tests and, mainly, with group activities, carried out in practically all observations. On her own practice, she conducts the assessment through feedback that asks students. She believes she was indicated by the students for presenting an open relationship and dialogue that she maintains with them, by providing opportunities for reflection and relaxation, creating bonds. She also believes that the fact of presenting theoretical and practical mastery of the content taught is an easy time to teach, favoring the use of examples. The students who indicated her as one of the best professors in the course mentioned:

She has knowledge and mastery of the subject, has an explanation for all doubts, uses different materials, has very dynamic classes that facilitate learning and an ease in communication. (SI5)

The students who were in the classroom, in the moments of nonparticipant observation, reported that the positive characteristics are related to the use of everyday examples, encouragement to reflection, dynamic classes, objective explanation, use of group assessments, clarification doubts and that Isabella is always in a good mood. They consider the moments when she clarifies all doubts and loses the focus of the class to be bad and note her insecurity when questioning topics that are not their domain. 
It seeks, through reflection on its own practice, the adaptation of the teaching contents and strategies used, recognizing the need for constant learning to reach a new understanding and for that, I would like to take a master's degree.

\section{DISCUSSION}

Considering the MARP and PCK expression, it is observed that Content Knowledge appears to the freshman professor, as a strong component of his basic knowledge for teaching. This strong tendency to value content knowledge becomes the starting point for teaching initiation, when the professor understands the content to be taught and believes he is able to enter the classroom. Content Knowledge comprises the theoretical association with practice and its relationship with other specific theoretical knowledge ${ }^{(4)}$. And it exerts great influence, occupying a central place in the knowledge base for teaching, because knowledge or lack of it affects the selection of teaching materials, as well as the conduct of a discipline ${ }^{(9)}$.

However, content knowledge alone does not characterize a good professor, as if it were so, specialists in its content should be excellent professors and it is known that this is not true and, on the contrary, the inefficiency of classroom specialists is a of the main complaints of students ${ }^{(10)}$. Thus, in addition to content knowledge, General Pedagogical Knowledge is also required, when the preparation, representation, selection and adaptation of this content, require teaching strategies that enable student learning. The General Pedagogical Knowledge of the newcomers under study was not consciously scored, but it appears when it is observed in their practices, to conduct the meetings, the use of videos, expository classes, practical classes, group work and use dynamics that stimulate reflection and dialogue.

Content knowledge is essential for pedagogical practice and both the freshman and the experienced have it, and what differs them is the way in which teaching is offered to students ${ }^{(5)}$. That is, the expansion of your PCK and the way it is evidenced, at the time of teaching, in practice. Thus, content knowledge is an important and necessary prerequisite for teaching, but it is the PCK that connects the content with pedagogy, containing the specificities and knowledge of professors to teach a particular subject $^{(11)}$.

The PCK manifested in the classroom, at the time of teaching, showed the predominance of transference and explanations about the content, when Vanessa starts from the "leveling" of the class and Isabella wants to "transmit" the content, and both aspects are observed teaching positivists, characteristic of the behaviors and thoughts of freshman professors, that is, they appear as weaknesses of the PCK, which still have to improve. At the other extreme, interaction and didactic interrogation appear, demonstrating an attempt to balance a more rigid posture, with traditional methods and a more flexible posture, close to an intermediate professor, with more pedagogical knowledge and encouragement for students to reflect.

This flexibility is a characteristic that has already been shown in a study, indicates that students tend to recognize a good professor, as one who adopts liberating pedagogical practices, to the detriment of an authoritarian stance ${ }^{(12)}$.
These perceptions are evidenced in the speech of Vanessa's students, when they consider the excessive amount of content to be bad, but with the use of diversified teaching and safety strategies to clarify doubts, valuing the interaction with students and the methodology used. Isabella, on the other hand, uses examples and encourages student reflection, providing interactive and dynamic classes, data that appeared in the interview with students, when they report that they like group activities and the stimulus to reflection that it provides.

The reflective dialogue and the didactic question appear in the practices of experienced professors, who observe that in addition to the content domain, there is space for interaction with the development of the theme from the student's perspective, with the use of several didactic resources, providing a satisfactory teaching from the point of view of content, empathy and professional relevance. Practices a little different from the freshmen under study, who, when leveling the class to transmit their own knowledge, also demonstrate weaknesses in the understanding and applicability of active and liberating methods of teaching and learning ${ }^{(13-14)}$.

In the observed practices, the freshman professors rarely anticipated the contents or associated with other subjects and this is also one of the profound differences between the freshmen and the experienced ones, when the experienced ones have a PCK that allow a wide view of the content to be taught, which allows flexibility to choose the best teaching methods, while the freshman sees the unit fragmented and works with small pieces of information, with the content divided into parts, without being able to see its relationship with the whole ${ }^{(3)}$. Thus, to improve its curricular organization and didactic flexibility, knowing the curriculum is an important step for the development and strengthening of $\mathrm{PCK}^{(3)}$. The newcomers in the study report that they use the curriculum only to assist their teaching planning, organizing the content to be taught in the academic semester. This being one of the main difficulties in the beginning of the teaching activity of the freshmen, related to their education, which did not help them to think about the curriculum, from a broader perspective ${ }^{(3)}$. This knowledge of the curriculum and the educational context allows the professor to anticipate contents and disciplinary integration, stimulating the student's curiosity for the contents that are yet to come, in addition to enabling the connection of new knowledge that is in the process of construction.

Another important basic knowledge for teaching, knowledge about students, appears in the practice of the freshmen under study. What happens in Isabella's practice is the interaction with students, in an attempt to create bonds and, in Vanessa's practice (reported in the biographical interview), she demonstrates empathy, to approach and create bonds with students, when she shares their professional and personal trajectory and, thus, stimulates in the student the perception that walking is possible, occurring the sharing of various situations experienced by students, where they report their life experiences and get even closer to the professor, this being a strategy of creation of bonds to bring the class closer.

This empathy that the professor uses, appears as a new element of the PCK in this study, called the didactic bond, which differs from the didactic empathy ${ }^{(5)}$, in which the professor puts 
himself in the student's place, to try to explain the content of a form that is easy for the student to understand when interpreting a learning disability. In this context, the didactic link emerges as a strategy of approximation, to get to know students and instigate autonomy and the search for their personal and professional achievements. This establishment of bonds and the use of empathy are characteristics perceived in good professors, by the perception of students, when they not only expect a professional with technical-scientific skills, but also a professional capable of perceiving, understanding and helping them to learn effective ${ }^{(15)}$.

This willingness of professors to relate and interact makes it possible to know the collective and individual characteristics of students, creating an atmosphere of cooperation, where students make not only curricular commitments, but also the mobilization to learn and develop, promoting a better experience formative. And this more flexible attitude of the professor enables better learning, reinforcing the understanding that the knowledge necessary for the teaching practice called excellence are mobilized contingently by the professor from his reflection process ${ }^{(15)}$.

In addition to the didactic link, another new PCK indicator, entitled 'technological resources', also appears as a contribution of this study. Because the professors in study use the use of videos, indication of websites, use of films, exchange of information by e-mail, use of social networks and stimulating research on the internet as a learning strategy, with the use of so-called Digital Technologies Information and Communication (DTIC). DTIC's are important pedagogical resources used in education and Shulman, in his studies, had not yet addressed this technology, because at the time, issues involving technologies were not in evidence ${ }^{(16)}$.

This integration of pedagogy with technology provides effective learning experiences for students, thus, the use of technologies is not an isolated skill but an integrated form of knowledge, being intertwined with the pedagogical understandings in the teaching area, with the use innovative pedagogical practices. Thus, good teaching requires the careful integration of technological knowledge with content knowledge, with the aim of enabling learning ${ }^{(16-18)}$.

In relation to the PCK sources in the newbies under study, there is academic training in the area of content knowledge to be taught and this knowledge may come from the specific bibliography and accumulated studies on the subject ${ }^{(5)}$. Another source observed is related to the wisdom gained from the pedagogical practice, considering that the teaching experience has a positive effect on the PCK, that is, one also learns to be a professor by being ${ }^{(11)}$.

The wisdom from care practice emerges as a new source of basic knowledge for teaching, strongly valued by freshman professors, used to subsidize and strengthen their pedagogical moments. However, this knowledge from the professional practice of nurses is not enough to promote learning, although it contributes to the construction of teaching knowledge and it is assumed that the professor builds knowledge in his classroom in contact with students. students, defined as a totally different knowledge from the formal knowledge learned in the academy ${ }^{(19)}$.

This professional practice allows the professor to include examples and share experiences that enrich the manifestation of their PCK, allowing the student to realistically understand the manifestation of the content, which is still, to some extent, abstract, for something more understandable when demonstrated by the professor's practical experience. However, it is understood that each profession requires a body of knowledge for teaching, in addition to content knowledge, which is the main domain that the professor must present, and then other skills are required, which can be developed in professor training ${ }^{(10)}$. Thus, preparation for teaching requires the appropriation of learning theories to understand the inseparability between contents and methods in the teaching-learning process ${ }^{(20)}$.

To achieve the objectives of organized schooling (teaching and learning), another source is needed, called pedagogical structures and materials and among them, institutional rules and professional professor organizations are included, with their political negotiation functions, expressing knowledge of the territory teaching performance, where these contextual conditions can facilitate or inhibit efforts to teach ${ }^{(5)}$. This source was not observed in the freshmen under study, as well as research on the school process, which is formal academic training in education, with the appropriation of the normative and theoretical aspects of academic knowledge about teaching, expressing the absence of recognition of teaching as a profession. The absence of these two sources and the strong valuation of wisdom from the care practice, express the characteristic of the freshman professor, when to strengthen his PCK, they feed, initially, on the knowledge of the theoretical and practical content to be taught.

The professor needs to learn to unlearn and reflect constantly and constructively on all aspects related to learning ${ }^{(21)}$. This movement of the action model and pedagogical reasoning requires that the professor's reasoning process about the basic knowledge for teaching is in continuous restructuring and its dynamics is enriched by the contexts of the results obtained, in a dynamic and cyclical model of reflection and action ${ }^{(10)}$.

Professors will also need to dedicate an important part of their activity to professional and personal transformations, requiring adaptation and transformation of their knowledge to a wide variety of methodologies and alternatives that, in a combined way, will contribute to guide the student towards new learning objectives, recognizing and valuing professor education, not because of internal institutional policies for maintaining careers, but because of the need identified by professors in their daily practice ${ }^{(14)}$.

Thus, studies on PCK, at different times of teaching, contribute to the professional development of professors, as they provide elements necessary for curricular reforms for professor training, because when professor practice is accessed, explored and documented, the results can be used as a starting point for professor training for inexperienced professors, with the aim of improving their practices, as well as helping experienced professors to develop more reflective practices ${ }^{(10)}$.

\section{Study limitations}

The results present the freshman professor from two perspectives: Isabella, without previous pedagogical preparation, without practical experience, however, with mastery of the content she teaches; Vanessa, on the other hand, participated in pedagogical training meetings, shows her experience of the practice and mastery of the content she teaches. Thus, there are indications that, the practical experience, associated with the domain of the content, influences the manifestation of the PCK of the professor at the time of teaching, 
and it is recognized as limitations of this study, the fact that Isabella was not observed in the discipline of its practical domain, it is not possible to observe the manifestation of its PCK in this context.

\section{Contributions to nursing}

As subsidies to professor training, the importance of problematizing Shulman's theoretical framework is pointed out, so that professors reflect on the basic knowledge for teaching and its sources, aiming at the strengthening and expansion of the PCK, for a strengthened teaching practice and that enable qualified teaching.

\section{FINAL CONSIDERATIONS}

Among the basic knowledge for teaching, freshman professors give greater importance to content knowledge, used to support and strengthen teaching practice, identified as their starting point. As a source of the PCK, they feed, primarily, on the wisdom derived from the care practice, thus emerging a new source of the basic knowledge for teaching. The PCK manifested in the classroom, at the time of teaching, through its indicators, made it possible to identify the transition from a traditional teaching model to a more liberating and dialogical teaching, with the student's role, evidencing the expansion process of the PCK. As new PCK indicators that this study made it possible to identify are the didactic link and the use of technological resources.

It is recognized in the freshmen'MARP, the presence of reflection in action, with learning in and about the pedagogical practice itself and this manifestation of a more reflective thinking of the professors, is expressed when seeking to strengthen their knowledge, demonstrating a perception of teaching professionalization. PCK studies provide elements for developing professor training strategies, whether for freshman, intermediate or experienced professors. Thus, for this gradual transition, with the consequent strengthening of the PCK, professor training meetings are essential, when in addition to personal engagement, institutional engagement is also necessary to promote pedagogical strengthening meetings, with a continuous calendar.

\section{FUNDING/ACKNOWLEDGMENT}

This study was funded by CAPES Scholarship/Sandwich Doctorate Program Abroad (PDSE) - Process 88881.134121/2016-01; FUMDES scholarship holder from the Universidade de Santa Catarina Scholarship Program (UNIEDU Program).

\section{REFERENCES}

1. Shulman LS. Knowledge and Teaching: foundations of the new reform. Harv Educ Rev[Internet]. 1987[cited 2018 Oct 10];57(1):1-22. Available from: http://people.ucsc.edu/ ktellez/shulman.pdf

2. Backes VMS, Moya JLM, Prado ML. The construction process of Pedagogical Knowledge among nursing professors. Rev Latino-Am Enferm[Internet]. 2011[cited 2018 Oct 01];19(2):421-8. Available from: http://www.scielo.br/pdf/rlae/v19n2/pt_26.pdf

3. Gudmundsdóttir S, Shulman LS. Conocimiento didáctico en ciencias sociales. Professorado[Internet]. 2005[cited 2018 Oct 01];9(2). Available from: https://www.ugr.es/ recfpro/rev92ART5.pdf

4. Shulman LS. Those who understand: knowledge growth in teaching. Educ Res[Internet]. 1986[cited 2018 Oct 01];15(5):4-14. Available from: http://www.fisica.uniud.it/URDF/masterDidSciUD/materiali/pdf/Shulman_1986.pdf

5. Shulman LS. Conocimiento y enseñanza: fundamentos de la nueva reforma. Profesorado[Internet]. 2005[cited 2018 Oct 01];9(2). Available from: https://www.ugr.es/ recfpro/rev92ART1.pdf

6. Marcon D, Graça ABS, Nascimento JV. Busca de paralelismo entre conhecimento pedagógico do conteúdo e processo de raciocínio e ação pedagógica. Educ Rev[Internet]. 2011 [cited 2018 Oct 01];27(1):261-94. Available from: https://www.scielo.br/pdf/edur/v27n1/v27n1a12.pdf

7. Fernandes CNS, Souza MCBM. Docência no ensino superior em enfermagem e constituição identitária: ingresso, trajetória e permanência. Rev Gaúcha Enferm. 2017;38(1):e64495. Available from: doi: 10.1590/1983- 1447.2017.01.64495

8. Stake RE. A arte da investigação com estudos de caso. Lisboa: Fundação Calouste Gulbenkian, 2012.

9. Grossman PL, Wilson SM, Shulman LS. Profesores de sustancia: el conocimiento de la materia para la enseñanza. 2011. Profesorado[Internet]. 2005[cited 2018 Oct 01];9(2):1-25. Available from: http://digibug.ugr.es/bitstream/10481/15261/1/rev92ART2.pdf

10. Keller MM, Neumann K, Fischer HE. The impact of physics teachers' pedagogical content knowledge and motivation on students' achievement and interest. J Res Sci Teach. 2016;54(5):586-614. doi: 10.1002/tea.21378

11. Koh JHL, Chai CS; Tay LY. TPACK-in-Action: Unpacking the contextual influences of teachers' construction of technological pedagogical content knowledge (TPACK). Comput Educ. 2014;78:20-29. doi: 10.1016/j.compedu.2014.04.022

12. Menegaz JC, Backes VMS, Medina JL, Prado ML, Canever BP. Pedagogical practices of good nursing, medicine and dentistry professors from the students' perception. Texto Contexto Enferm. 2015;24(3):629-36. doi 10.1590/0104-07072015002790014

13. Silva JP, Gonçalves MFC, Andrade LS, Monteiro EMLM, Silva MAI. Health promotion in primary education: perceptions of bachelor's degree with a teaching diploma in nursing students. Rev Gaúcha Enferm. 2018;39:e2017-0237. doi: 10.1590/1983-1447.2018.2017-0237

14. Backes VMS, Moya JLM, Prado ML, Menegaz JC, Cunha AP, Francisco BS. Expressões do conhecimento didático do conteúdo de um professor experimentado de enfermagem. Texto \& Contexto Enferm[Internet]. 2013[cited 2018 Oct 01];22(3):804-10. Available from: http://www. scielo.br/scielo.php?script=sci_arttext\&pid=S0104-07072013000300029 
15. Menegaz JC, Backes VMS. Bons professores de enfermagem, medicina e odontologia: Percepção acerca do conhecimento sobre os alunos. Esc Anna Nery [Internet]. 2016[cited 2018 Oct 01];20(2):268-74. Available from: http://www.scielo.br/pdf/ean/v20n2/1414-8145ean-20-02-0268.pdf

16. Koh JHL, Chai CS, Benjamin W, Hong HY. Technological Pedagogical Content Knowledge (TPACK) and design thinking: a framework to support ICT lesson design for 21st Century Learning. Asia-Pacific Educ Res[Internet]. 2015[cited 2018 Dec 11];24(3):535-43. Available from: https://link.springer.com/article/10.1007/s40299-015-0237-2

17. Drummond A, Sweeney T. Can an objective measure of technological pedagogical content knowledge (TPACK) supplement existing TPACK measures? Br J Educ Technol[Internet]. 2017[cited 2018 Dec 10];48(4):928-39. Available from: https://doi.org/10.1111/bjet.12473

18. Rolando LGR, Luz MRMP, Salvador DF. O conhecimento tecnológico pedagógico do conteúdo no contexto lusófono: uma revisão sistemática da literatura. Rev Bras Inform Educ[Internet] 2015[cited 2018 Oct 23];23(3):174-90. Available from: https://doi.org/10.5753/ RBIE.2015.23.03.174

19. Amestoy SC, Backes VMS, Thofehrn MB, Martini JG, Meirelles BHS, Trindade LL. Percepção dos enfermeiros sobre o processo de ensinoaprendizagem da liderança. Texto Contexto Enferm. 2013;22(2):468-75. doi: 10.1590/S0104-07072013000200024

20. Damiance PRM, Tonete VLP, Daibem AML, Ferreira MLSM, Bastos JRM. Training for the uhs: an analysis of the pedagogical conceptions and practices in public health. Trab Educ Saúde. 2016;14(3):699-721. doi: 10.1590/1981-7746-sol00014

21. Aguilar LCG, Pulido CF, Rivera DCO, Ramírez MCM. The meaning of teaching and learning for professors. Invest Educ Enferm[Internet]. 2015[cited 2018 Oct 01];33(1):8-16. Available from: http://www.scielo.org.co/pdf/iee/v33n1/v33n1a02.pdf 